\title{
Article \\ Anisometric Ln(III) Complexes with Efficient Near-IR Luminescence
}

\author{
Andrey A. Knyazev ${ }^{1, *(\mathbb{D}}$, Aleksandr S. Krupin ${ }^{1}$ and Yuriy G. Galyametdinov ${ }^{1,2}$ \\ 1 Physical and Colloid Chemistry Department, Kazan National Research Technological University, \\ 68 Karl Marx, 420015 Kazan, Russia; krupin_91@mail.ru (A.S.K.); yugal2002@mail.ru (Y.G.G.) \\ 2 Laboratory of Fast Molecular Processes, Zavoisky Physical-Technical Institute, FRC Kazan Scientific Center of \\ RAS, 10/7 Sibirsky Tract, 420029 Kazan, Russia \\ * Correspondence: knjazev2001@mail.ru
}

Citation: Knyazev, A.A.; Krupin, A.S.; Galyametdinov, Y.G.

Anisometric Ln(III) Complexes with Efficient Near-IR Luminescence. Inorganics 2022, 10, 9. https:// doi.org/10.3390/inorganics10010009

Academic Editor: Antonino Gulino

Received: 6 December 2021

Accepted: 7 January 2022

Published: 11 January 2022

Publisher's Note: MDPI stays neutral with regard to jurisdictional claims in published maps and institutional affiliations.

Copyright: (C) 2022 by the authors. Licensee MDPI, Basel, Switzerland. This article is an open access article distributed under the terms and conditions of the Creative Commons Attribution (CC BY) license (https:// creativecommons.org/licenses/by/ $4.0 /)$.

\begin{abstract}
Recent studies in development of near-infrared luminophores focus on overcoming their disadvantages such as low quantum efficiency, limited emission power, and broad emission spectra. Rare earth (RE) elements are promising compounds in this respect as they offer a unique set of optical properties that provide narrow emission spectra and large Stokes shifts. This work reports the results of synthesis and characterization of new anisometric complexes of lanthanide(III) tris(b-diketonates) and 1,10-phenanthroline. These complexes possess light emitting-properties in the near-infrared range. Due to their structural features, these complexes allow production of homogeneous films by spin coating. These films are transparent in the visible and near-infrared ranges (transmission up to $99 \%$ ). This paper demonstrates advantages of $\mathrm{Yb}(\mathrm{III}), \mathrm{Er}(\mathrm{III})$, and $\mathrm{Nd}(\mathrm{III})$ complexes as potential components of highly efficient light-transforming NIR coatings.
\end{abstract}

Keywords: lanthanide complexes; NIR luminescence; light-transforming coatings

\section{Introduction}

Infrared radiation (IR) attracts the sustained attention of scientists due to growing opportunities for its practical applications [1-6]. Most of these applications rely on the results of research in physics, chemistry, pharmacy, medicine, cosmetics, food sciences, and agriculture [1]. Various IR light sources are represented by tungsten halogen lamps, Globars, and light-emitting diodes with luminophore conversion (PC light emitting diodes) [7]. Selection of a proper IR luminophore depends primarily on its emission wavelength, full width at half maximum (FWHM), efficiency, service life, and thermal stability. Today, PC LEDs are popular near-infrared (NIR) light sources that are used as components of remote control devices, automobile sensors, traffic enforcement cameras, ocular scanners, spectrometers, optic fiber devices, and biological analysis instruments [8-18]. Near-infrared PC LEDs demonstrate a longer service life of up to $100,000 \mathrm{~h}$. They are cost-effective devices due to their small size [7].

Recent research activities in development of near-infrared luminophores focus on overcoming their disadvantages such as low quantum efficiency, limited emission power, and broad emission spectra [19-22]. Rare earth (RE) elements make a substantial contribution to solving these problems because they offer a unique set of optical properties such as narrow emission spectra and large Stokes shifts [23]. With the exception of lanthanum and lutetium, $\mathrm{Ln}^{3+}$ ions generate stable long-life $f$-f-emissions in response to a direct photoexcitation within absorption wavelengths of metals. The advantages of lanthanide complexes as components of optoelectronic devices are their narrow emission bands and broad light color options offered by lanthanide ions: Tm(III)—blue, Tb(III)—green, Eu(III)—red, Dy(III)—yellow, Sm(III)—orange, Nd(III), Er(III) and $\mathrm{Yb}(\mathrm{III})$ - infrared. By combining these complexes with various ions, we can generate emission of virtually any color such as a white color emission. However, molar absorption coefficients of inorganic $\mathrm{Ln}^{3+}$ compounds 
are usually very small $(\varepsilon=0.01-10 \mathrm{~L} /(\mathrm{mol} \times \mathrm{cm}))$. They are limited by parity-forbidden $f$-f-transitions [24]. Compounds allowing one to overcome these limitations are organic ligands with absorbing chromophore groups. These groups transmit energy to the emission level of a metal ion (an antenna effect) [25]. They should satisfy the following two criteria. Firstly, a suitable chromophore should be a good sensibilizer of $\mathrm{Ln}^{3+}$ ions [17]. Secondly, the resulting compounds should be thermally and chemically stable and possess good mechanical properties for possible practical applications in molecular electronics [26]. Ligands represented by $\beta$-diketones possess strong broadband absorption properties. They are among the most studied chromophores for neutral tris( $\beta$-diketonate) [27] or anionic tetrakis( $\beta$-diketonate) $\mathrm{Ln}^{3+}$ complexes [28]. These compounds perform an efficient transfer of energy to the $\mathrm{Eu}^{3+}$ and $\mathrm{Tb}^{3+}$ ions and generate a relatively high first excited state $\left({ }^{5} \mathrm{D}_{0}\right.$ for $\mathrm{Eu}^{3+}$ is $17,286 \mathrm{~cm}^{-1}$ and ${ }^{5} \mathrm{D}_{4}$ for $\mathrm{Tb}^{3+}$ is $20,545 \mathrm{~cm}^{-1}$, respectively) [29,30]. On the other hand, less detailed studies are reported for complexes of lanthanide $\beta$-diketonates generating emissions in the near-infrared range [31,32]. Due to their monochromatic NIR luminescence properties, such substances exhibit potential for applications in telecommunications, biology, and laser technologies [24,33-35].

In addition to these peculiar features, lanthanide materials demonstrate less intensive NIR light scattering in biological systems. The emission band of such materials is, therefore, within the biological transparency window $(\lambda=700-1100 \mathrm{~nm})$, so they are particularly attractive for generation of detailed images of thick tissues with time synchronization [36-39]. Thus, synthesis and characterization of new rare earth coordination compounds with IR luminescence properties represent an urgent problem of modern science.

This work reports the results of synthesis and characterization of new anisometric complexes of lanthanide(III) tris(b-diketonates) and 1,10-phenanthroline that possess light emitting-properties in the near-infrared range.

\section{Results and Discussion}

Ligands represented by $\beta$-diketonates possess strong broadband absorption properties. Such ligands are among the most studied chromophores for the synthesized neutral tris- $\beta$ diketonate [27] or anionic tetrakis- $\beta$-diketonate $\mathrm{Ln}^{3+}$-complexes [28]. Efficient sensitization of visible light luminescence is reported for $\mathrm{Eu}^{3+}$ and $\mathrm{Tb}^{3+}$ ions with relatively high first excited states $\left({ }^{5} \mathrm{D}_{0}\right.$ for $\mathrm{Eu}^{3+}$ is $17,286 \mathrm{~cm}^{-1}$ and ${ }^{5} \mathrm{D}_{4}$ for $\mathrm{Tb}^{3+}$ is $\left.20,545 \mathrm{~cm}^{-1}\right)[29,30,40]$. There is, however, an unresolved problem of synthesis of a suitable $\beta$-diketonate ligand with a relatively lower triplet energy level that matches the first excited state of NIR-luminescent $\mathrm{Ln}^{3+}$ ions $[41,42]\left({ }^{4} \mathrm{~F}_{3 / 2}\right.$ for $\mathrm{Nd}^{3+}$ is $11,257 \mathrm{~cm}^{-1} ;{ }^{2} \mathrm{~F}_{5 / 2}$ for $\mathrm{Yb}^{3+}$ is $10,400 \mathrm{~cm}^{-1}$, and ${ }^{4} \mathrm{I}_{13 / 2}$ for $\mathrm{Er}^{3+}$ is $6610 \mathrm{~cm}^{-1}$ ). According to the literature data, ligands with the triplet energy levels from $18,000 \mathrm{~cm}^{-1}$ to $21,000 \mathrm{~cm}^{-1}$ are used to synthesize $\beta$-diketonate lanthanide complexes with the NIR-emission properties (Table 1). A possible approach to intensifying luminescence in the near-infrared range and minimizing a non-radiative deactivation is to use $\beta$-diketonate ligands that contain fluorine $[43,44]$. Another approach is to reduce the triplet energy level of a ligand by adding conjugated bonds [45].

Previously, the authors synthesized a large number of $\beta$-diketones with various substituents that allow alteration of the triplet level of a ligand (Table 1). In the earlier works, however, these $\beta$-diketones were used to synthesize lanthanide(III) complexes, which possess visible light emission properties. The triplet level of a ligand was, therefore, selected to efficiently sensitize the visible light luminescence of the $\mathrm{Eu}^{3+} \mathrm{Sm}^{3+}$, or $\mathrm{Tb}^{3+}$ ions with relatively high first excited states $[46,47]$. In this work, the structures of $\beta$-diketones were selected according to the following criteria: (a) matching the triplet level energy values of similar compounds, which are known to be used for coordinating NIR-luminescent $\mathrm{Ln}^{3+}$ ions; (b) demonstrating good solubility in organic solvents; (c) possessing an amorphous structure provided by long hydrocarbon or cyclohexane substituents that allows fabrication of homogeneous and defectless films. Compounds that satisfy these criteria can be potential components of film coatings for PC light-emitting diodes. 
Table 1. Structures and triplet levels of some $\beta$-diketones.

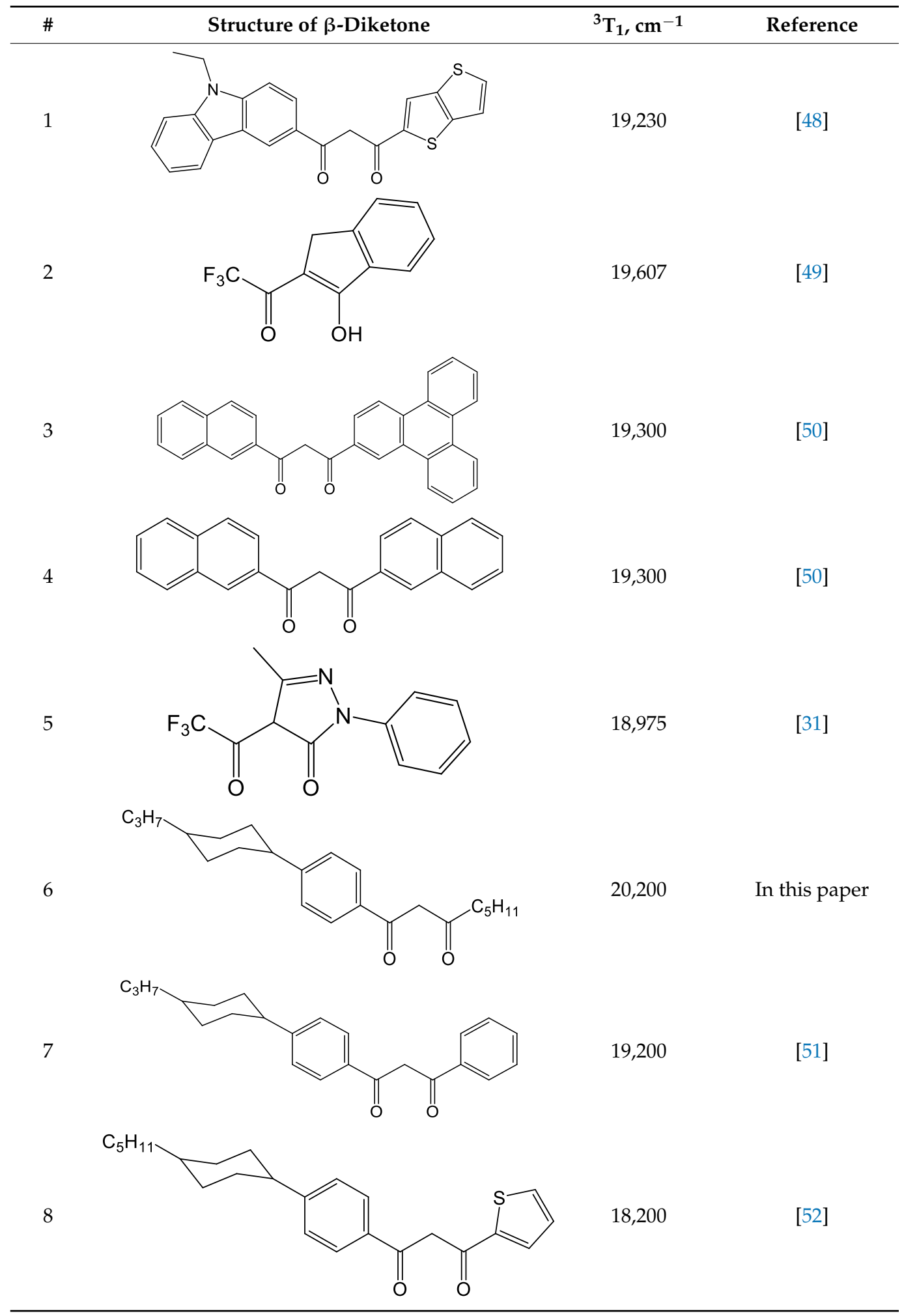


Table 1. Cont.

$\#$

We synthesized complexes of lanthanide (III) tris( $\beta$-diketonates) and 1,10-phenanthroline. The molecular structure of these complexes has an anisometric geometry (Figure 1) [55-57]. Original $\beta$-diketones and 1,10-phenanthroline were used as the ligands. Their triplet levels perform efficient energy transfer to the emitting levels of the $\mathrm{Ln}^{3+}$ ions. The composition and structure of these complexes were confirmed by elemental analysis and mass spectrometry. The synthesized compounds are amorphous powders due to their anisotropy and long hydrocarbon substituents at molecular edges. The anisometric molecular structure of such complexes was confirmed by previous quantum chemistry calculations and X-ray diffraction characterization performed by the authors for similar Eu(III) complexes. These powders demonstrate good solubility in nonpolar or low-polar organic solvents.

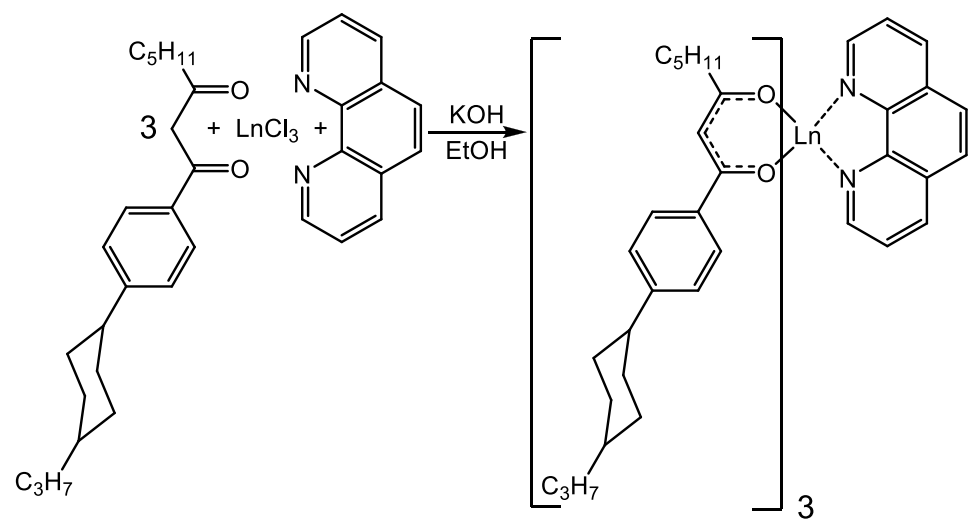

$\mathrm{Ln}=\mathrm{Pr}, \mathrm{Nd}, \mathrm{Sm}, \mathrm{Gd}, \mathrm{Ho}, \mathrm{Er}, \mathrm{Yb}$

Figure 1. Synthesis of tris( $\beta$-diketonate) lanthanide(III) complexes with 1,10-phenanthroline.

The solutions of these complexes in toluene $\left(1 \times 10^{-3} \mathrm{~mol} / \mathrm{L}\right)$ were used to fabricate films with the thickness of $100 \pm 5 \mathrm{~nm}$ by spin coating [51]. We characterized optical properties of both solutions and films that contained La(III) complexes. The maximums of the UV/VIS absorption spectra obtained for the Ln(III) complexes dissolved in hexane ( $c=1 \times 10^{-5} \mathrm{~mol} / \mathrm{L}$, Figure $2 \mathrm{a}$ ) are similar to the maximums observed for the individual ligands. Due to their structural features, these complexes allow production of homogeneous films by the spin coating deposition from their solutions. These films are transparent in the visible and near-infrared ranges (light transmission up to 99\%) (Figure 2b). 


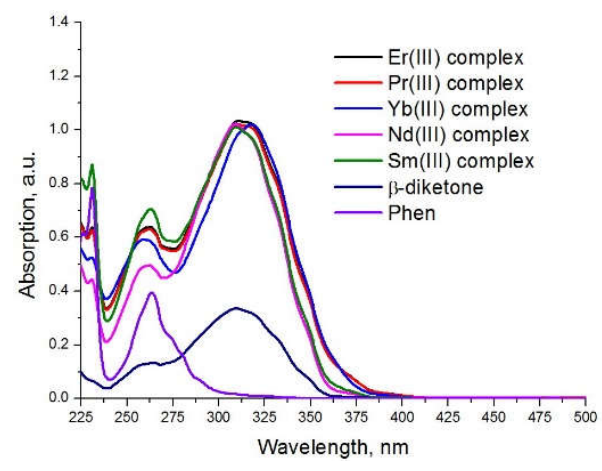

(a)

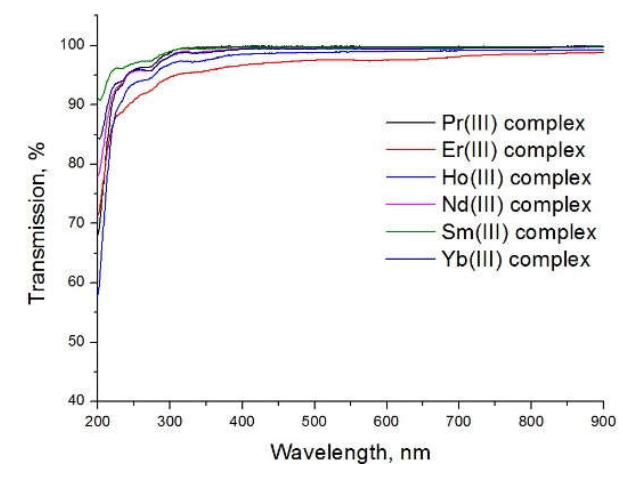

(b)

Figure 2. (a) Absorption spectra of lanthanide(III) complexes and ligands dissolved in hexane with the concentration of $10^{-5} \mathrm{~mol} / \mathrm{L}$; (b) transmittance spectra of the films containing lanthanide(III) complexes.

To determine the energy levels of the ligand environment, we studied the luminescent properties of the gadolinium $\mathrm{Gd}(\mathrm{III})$ complexes that were incorporated into thin films by spin coating at the temperature of liquid nitrogen $(\mathrm{T}=77 \mathrm{~K})$ (Figure 3). $\mathrm{A} \mathrm{Gd}^{3+}$ ion does not emit light because its first excited ${ }^{6} \mathrm{P}_{7 / 2}$-level $\left(32,000 \mathrm{~cm}^{-1}\right)$ is above the lower triplet level of the majority of known organic ligands. According to the literature data, most $\beta$-diketonate $\mathrm{Gd}(\mathrm{III})$ complexes exhibit only phosphorescence at $77 \mathrm{~K}$ due to their efficient intercombinational conversion [58]. The central ion does not exert a substantial impact on the excited energy levels of the ligands. Similar energy levels can be, therefore, observed for other $\operatorname{Ln}(\mathrm{III})$ ions.

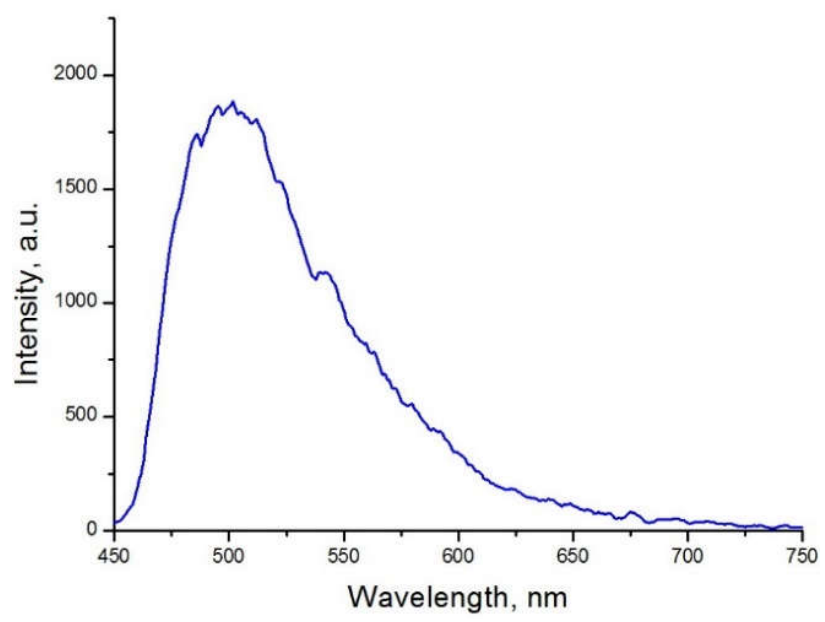

Figure 3. Luminescence spectrum of the films with the Gd(III) complexes at $\mathrm{T}=77 \mathrm{~K}$.

The experimental phosphorescence spectrum of $\mathrm{Gd}(\mathrm{III})$ allowed attainment of the value of the $\beta$-diketonate triplet level equal to approximately $20,200 \mathrm{~cm}^{-1}$. The triplet levels of the ligands and the emission transitions of the lanthanide ions are summarized in the energy level diagram that represents the energy transfer processes occurring in the synthesized complexes. This diagram is shown in Figure 4. 


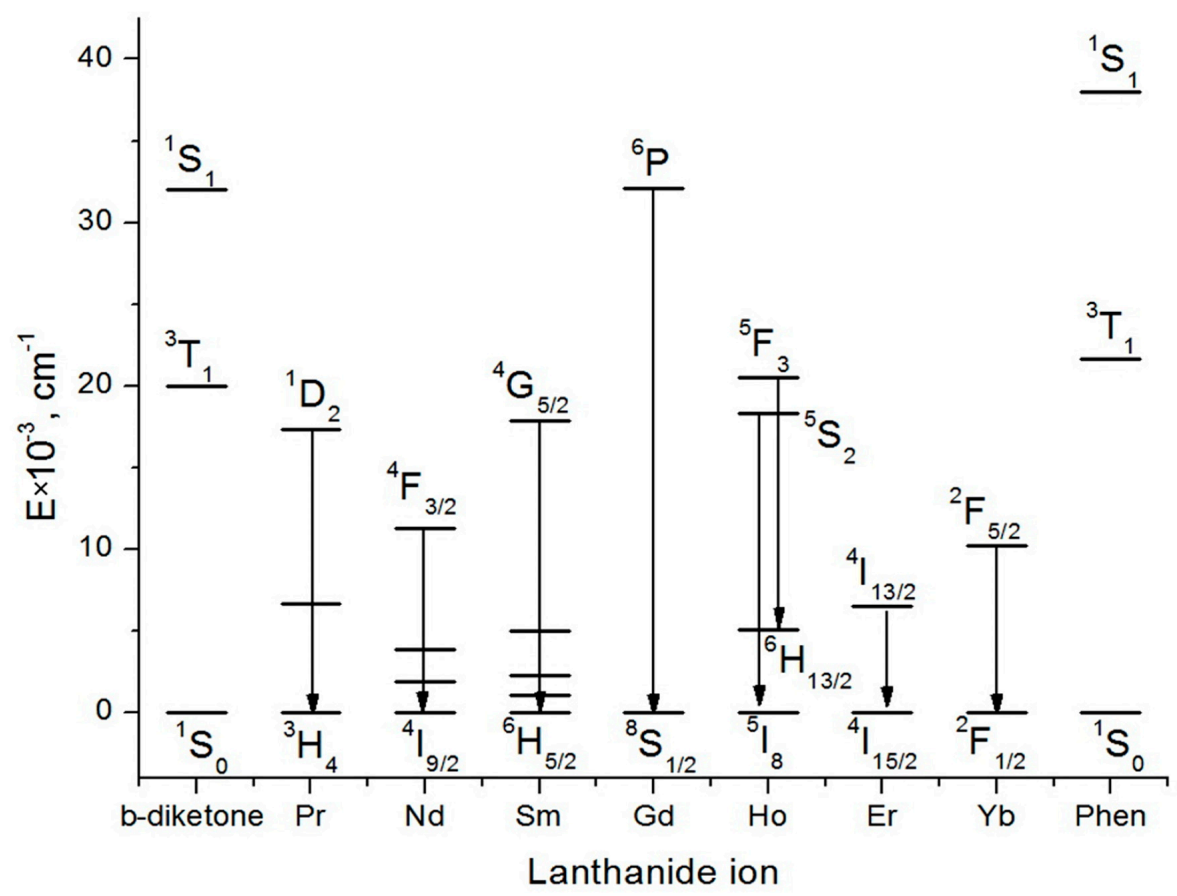

Figure 4. Energy levels of the synthesized complexes.

We can see in this diagram that the triplet energy levels of the $\beta$-diketone and the Lewis base are slightly higher than the resonance levels of virtually all the lanthanide ions discussed in this work. Such properties should favor the transfer of energy (an antenna effect) and efficient luminescence in the near-infrared range $[59,60]$.

To evaluate applicability of the synthesized complexes to producing conversion coatings for PC-LEDs, we obtained the luminescence spectra of the films by using a $408 \mathrm{~nm}$ blue light emitting diode as the source of the excitation light. The emission spectra of the $\mathrm{Sm}$ (III) complexes obtained at room temperature show the characteristic samarium ion transition bands at the wavelengths of 800-1400 nm. The observed high-resolution peaks represent the transitions from the ${ }^{4} \mathrm{G}_{5 / 2}$ level of the excited state to the ${ }^{6} \mathrm{H}_{j}$ sub-levels of the main multiplet. The maximum intensities of the characteristic peaks at the wavelengths of $887,909,927,952$, and $1036 \mathrm{~nm}$ correspond to the transitions from the ${ }^{4} \mathrm{G}_{5 / 2}$ level of the excited state to the ${ }^{6} \mathrm{~F}_{\mathrm{J}}$ sub-levels of the main multiplet $(\mathrm{J}=1 / 2,3 / 2,5 / 2,7 / 2$, and 9/2) (Figure 5a). The peaks at the wavelengths of 1130, 1210, and $1300 \mathrm{~nm}$ correspond to the second harmonic of the transitions from the ${ }^{4} \mathrm{G}_{5 / 2}$ level of the excited state to the ${ }^{6} \mathrm{H}_{\mathrm{J}}$ sub-levels of the main multiplet $(J=5 / 2,7 / 2,9 / 2)$.

The emission spectrum of the $\mathrm{Yb}(\mathrm{III})$ complex contains several intensive lines at $976 \mathrm{~nm}$ with the lifetime $\tau=11 \mu \mathrm{s}$, which correspond to the Stark splitting of the ${ }^{2} \mathrm{~F}_{5 / 2} \rightarrow{ }^{2} \mathrm{~F}_{7 / 2}$ transition (Figure $5 \mathrm{~b}$ ) and fit the middle of the first biological transparency window $(\lambda=700-1100 \mathrm{~nm})$. In combination with a two-photon excitation technique, such compounds of $\mathrm{Yb}$ (III) become attractive substances for biological research techniques [61]. The $\mathrm{Nd}$ (III) complex shows three luminescence peaks that correspond to the ${ }^{4} \mathrm{~F}_{3 / 2} \rightarrow{ }^{4} \mathrm{I}_{\mathrm{J}}$ transitions $(J=9 / 2,11 / 2,13 / 2)$ with the lifetime $\tau=9 \mu$ s (Figure 5c).

The luminescence spectra of the $\operatorname{Er}(\mathrm{III})$ complexes contain a single line corresponding to the ${ }^{4} \mathrm{I}_{13 / 2} \rightarrow{ }^{4} \mathrm{I}_{15 / 2}$ transition at $1530 \mathrm{~nm}$ in the near-infrared range of the spectrum with the lifetime $\tau=3 \mu \mathrm{s}$ (Figure $5 \mathrm{~d}$ ) that can be used in laser technologies and telecommunications. The $\operatorname{Pr}(\mathrm{III})$ complex demonstrates a relatively low characteristic peak corresponding to the ${ }^{1} \mathrm{D}_{2} \rightarrow{ }^{3} \mathrm{H}_{4}$ transition at $1060 \mathrm{~nm}$ (Figure 5e). The Ho(III) complex exhibits a noise-level IR luminescence. The spectra reveal that the luminescence intensity of the films that contain the $\mathrm{Yb}(\mathrm{III})$ и $\mathrm{Nd}(\mathrm{III})$ complexes is almost two times higher than that of the films containing the $\mathrm{Er}(\mathrm{III})$ and $\mathrm{Sm}$ (III) compounds and six times higher than the luminescence intensity 
of the films containing the $\operatorname{Pr}(\mathrm{III})$ complex. Therefore, the most intensive luminescence is demonstrated by the compounds that contain $\mathrm{Yb}(\mathrm{III}), \mathrm{Er}(\mathrm{III})$, or $\mathrm{Nd}(\mathrm{III})$ ions.

This work, therefore, demonstrates a potential of using $\mathrm{Yb}(\mathrm{III}), \mathrm{Er}(\mathrm{III})$ and $\mathrm{Nd}(\mathrm{III})$ complexes as components of highly efficient light-transforming NIR coatings for PC light emitting diodes.

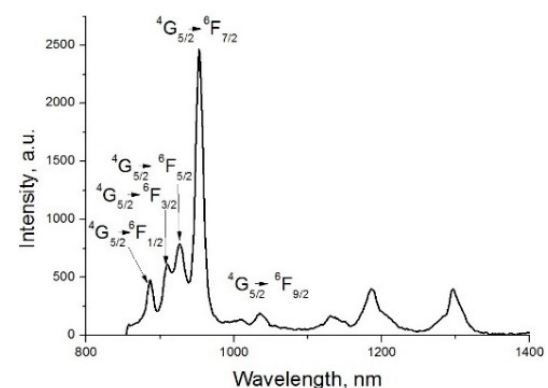

(a)

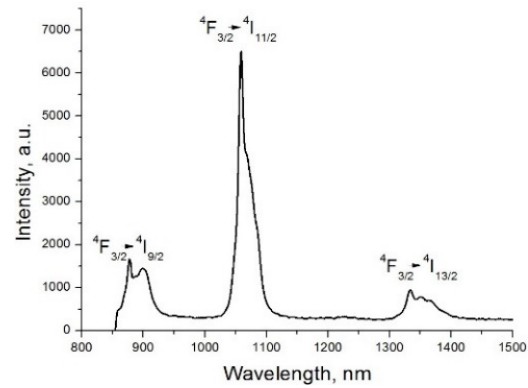

(c)

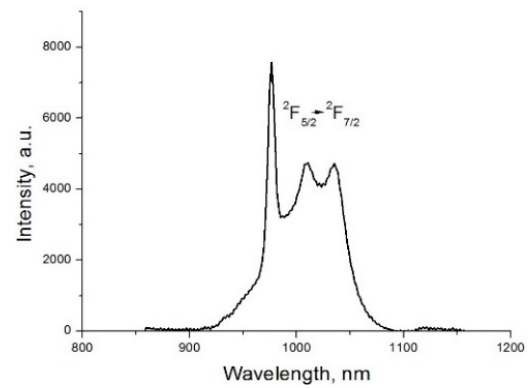

(b)

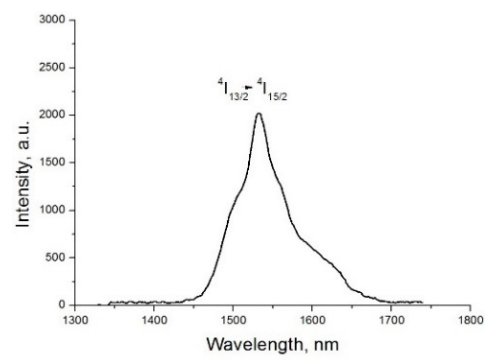

(d)

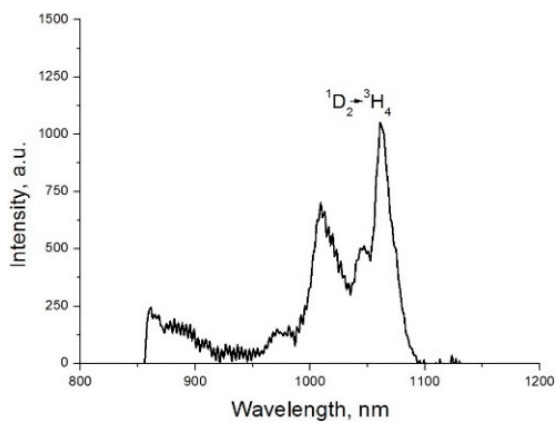

(e)

Figure 5. Luminescence spectra of the films containing (a) $\mathrm{Sm}$ (III), (b) $\mathrm{Yb}$ (III), (c) $\mathrm{Nd}$ (III), (d) $\operatorname{Er}(\mathrm{III})$ and (e) $\operatorname{Pr}(\mathrm{III})$ complexes in the near IR range.

\section{Materials and Methods}

\subsection{Materials}

Praseodymium(III) chloride hexahydrate (99.9\%), neodymium(III) chloride hexahydrate $(99.9 \%)$, samarium(III) chloride hexahydrate $(99.99 \%)$, gadolinium(III) chloride hexahydrate $(99.999 \%)$, holmium(III) chloride hexahydrate (99.9\%), erbium(III) chloride hexahydrate (99.9\%), ytterbium(III) chloride hexahydrate (99.9\%), and 1,10-phenanthroline $(99 \%)$ were purchased from Sigma-Aldrich.

\subsection{Characterization Techniques}

CHN elemental microanalysis was performed with a Delta V Plus isotope mass spectrometer (Thermo Fisher Scientific, Braunschweig, Germany). X-ray fluorescence analysis was performed with a Bruker M4 «Tornado» spectrometer. The mass spectra data were 
obtained by a Bruker Esquire LC-Ion Trap Mass Spectrometer. Absorption and transmission spectra were measured by a Perkin-Elmer Lambda-35 UV/Vis spectrophotometer. Luminescence spectra of the produced films were recorded by an Ocean optics NIR Quest 512 spectrofluorimeter (Bridge Tronic Global Inc, Costa Mesa, CA, USA). The excitation wavelength was set to $408 \mathrm{~nm}$.

\subsection{Synthesis of Complexes}

The 1-[4-(4-propylcyclohexyl)phenyl]-octane-1,3-dione ligand was synthesized according to the modified procedures reported in the literature $[52,62]$.

Ln(III) complexes [63] were synthesized according to the following general procedure: ethanol solutions of $\mathrm{LnCl}_{3} \times 6 \mathrm{H}_{2} \mathrm{O}(\mathrm{Ln}=\mathrm{Pr}, \mathrm{Nd}, \mathrm{Sm}, \mathrm{Gd}, \mathrm{Ho}$, Er or $\mathrm{Yb})(0.1 \mathrm{mmol})$ were added dropwise to a stirred hot ethanol solution that contained $\beta$-diketone (1-[4-(4propylcyclohexyl)phenyl]-octane-1,3-dione) (0.3 mmol), 1,10-Phenanthroline (0.1 mmol), and $\mathrm{KOH}(0.35 \mathrm{mmol})$. The resulting light-yellow precipitates were filtered from their solutions, washed by hot alcohol, and dried under vacuum. The dry product was dissolved in toluene, filtered again, and dried under vacuum (Table 2).

Table 2. The results of the analysis of synthesized $\operatorname{Ln}(\mathrm{III})$ complexes.

\begin{tabular}{|c|c|c|c|c|c|c|c|c|c|c|c|c|}
\hline \multirow{3}{*}{ Lanthanide Ion } & \multirow{3}{*}{ Yield, \% } & \multicolumn{10}{|c|}{ Elemental } & \multirow{3}{*}{ ESI-MS $(\mathrm{m} / \mathrm{z})$} \\
\hline & & \multicolumn{2}{|c|}{ C, \% } & \multicolumn{2}{|c|}{$\mathrm{H}, \%$} & \multicolumn{2}{|c|}{$\mathrm{N}, \%$} & \multicolumn{2}{|c|}{$\mathrm{O}, \%$} & \multicolumn{2}{|c|}{ Ln, \% } & \\
\hline & & Calcd. & Found & Calcd. & Found & Calcd. & Found & Calcd. & Found & Calcd. & Found & \\
\hline $\operatorname{Pr}$ & 75 & 72.30 & 72.01 & 8.01 & 8.17 & 2.08 & 2.05 & 7.13 & 7.22 & 10.47 & 10.45 & $1368(\mathrm{M}+\mathrm{Na})^{+}$ \\
\hline $\mathrm{Nd}$ & 73 & 72.12 & 71.98 & 7.99 & 8.06 & 2.08 & 2.05 & 7.12 & 7.26 & 10.69 & 10.81 & $1370(\mathrm{M}+\mathrm{Na})^{+}$ \\
\hline $\mathrm{Sm}$ & 78 & 71.79 & 71.59 & 7.96 & 8.12 & 2.07 & 2.04 & 7.08 & 7.23 & 11.10 & 11.47 & $1377(\mathrm{M}+\mathrm{Na})^{+}$ \\
\hline $\mathrm{Gd}$ & 74 & 71.43 & 71.25 & 7.92 & 8.15 & 2.06 & 2.04 & 7.05 & 7.27 & 11.55 & 11.63 & $1385(\mathrm{M}+\mathrm{Na})^{+}$ \\
\hline Ho & 71 & 71.03 & 70.87 & 7.87 & 8.11 & 2.05 & 2.02 & 7.01 & 7.42 & 12.04 & 12.16 & $1391(\mathrm{M}+\mathrm{Na})^{+}$ \\
\hline $\mathrm{Er}$ & 72 & 70.91 & 70.78 & 7.86 & 8.05 & 2.04 & 2.02 & 7.00 & 7.22 & 12.19 & 12.03 & $1394(\mathrm{M}+\mathrm{Na})^{+}$ \\
\hline $\mathrm{Yb}$ & 73 & 70.61 & 70.48 & 7.83 & 8.02 & 2.03 & 2.01 & 6.97 & 7.16 & 12.56 & 12.41 & $1399(\mathrm{M}+\mathrm{Na})^{+}$ \\
\hline
\end{tabular}

\section{Conclusions}

This paper reports synthesis of new anisotropic lanthanide(III) complexes that possess near-infrared luminescence properties. Due to their structural features, these complexes can be incorporated into homogeneous films by spin coating deposition from their solutions. The resulting films are transparent in the visible and near-infrared ranges (transmission up to $99 \%$ ). The synthesized $\mathrm{Yb}$ (III), $\mathrm{Er}$ (III) and $\mathrm{Nd}(\mathrm{III})$ compounds demonstrate efficient luminescence in the near-infrared range. By varying lanthanide(III) ions, we can control emission wavelengths of the produced films. Thus, this work demonstrates a possibility to use $\mathrm{Yb}(\mathrm{III}), \mathrm{Er}(\mathrm{III})$ and $\mathrm{Nd}(\mathrm{III})$ complexes for making highly efficient light-transforming NIR coatings for PC light emitting diodes. The emission bandwidth of the $\mathrm{Yb}(\mathrm{III})$ and $\mathrm{Nd}$ (III) complexes is within the biological transparency window $(\lambda=700-1100 \mathrm{~nm})$. Therefore, these complexes are attractive for biomedical applications such as performing a comprehensive study of thick tissues of the majority of living organisms. In its turn, the luminescence emission of the Er(III) compounds fits the third transparency window of optic fibers $(\lambda \approx 1550 \mathrm{~nm})$ and highlights potential applications of such compounds in the telecommunications industry.

Author Contributions: This work is the collaborative development of all the authors. Conceptualization, A.A.K. and Y.G.G.; methodology, A.A.K. and Y.G.G.; software, A.S.K.; validation, A.A.K., A.S.K. and Y.G.G.; formal analysis, A.S.K.; investigation, A.A.K., A.S.K. and Y.G.G.; resources, Y.G.G.; data curation, A.A.K. and Y.G.G.; writing-original draft preparation, A.A.K. and A.S.K.; writing-review and editing, Y.G.G.; supervision, A.A.K. and Y.G.G. All authors have read and agreed to the published version of the manuscript.

Funding: This research was funded by the Russian Science Foundation, grant number 20-73-10091.

Institutional Review Board Statement: Not applicable.

Informed Consent Statement: Not applicable. 
Data Availability Statement: Not applicable.

Acknowledgments: The study was carried out using the equipment of the Center for Collective Use "Nanomaterials and Nanotechnology" of the Kazan National Research Technological University.

Conflicts of Interest: The authors declare no conflict of interests.

\section{References}

1. Siesler, H.W.; Ozaki, Y.; Kawata, S.; Heise, H.M. Near-Infrared Spectroscopy: Principles, Instruments, Applications; John Wiley \& Sons: Hoboken, NJ, USA, 2008; ISBN 352761267X.

2. Ozaki, Y.; Huck, C.; Tsuchikawa, S.; Engelsen, S.B. Near-Infrared Spectroscopy: Theory, Spectral Analysis, Instrumentation, and Applications; Springer: Berlin/Heidelberg, Germany, 2021; ISBN 9811586489.

3. Wang, Z.Y. Near-Infrared Organic Materials and Emerging Applications; CRC Press: Boca Raton, FL, USA, 2013.

4. Svoboda, K.; Block, S.M. Biological applications of optical forces. Annu. Rev. Biophys. Biomol. Struct. 1994, 23, 247-285. [CrossRef]

5. Ferrari, M.; Wolf, M.; Quaresima, V. Progress of near-infrared spectroscopy and topography for brain and muscle clinical applications. J. Biomed. Opt. 2007, 12, 062104. [CrossRef]

6. Ntziachristos, V.; Bremer, C.; Weissleder, R. Fluorescence imaging with near-infrared light: New technological advances that enable in vivo molecular imaging. Eur. Radiol. 2003, 13, 195-208. [CrossRef] [PubMed]

7. Rajendran, V.; Chang, H.; Liu, R.-S. (INVITED) Recent progress on broadband near-infrared phosphors-converted light emitting diodes for future miniature spectrometers. Opt. Mater. X 2019, 1, 100011. [CrossRef]

8. Rajendran, V.; Fang, M.-H.; De Guzman, G.N.; Lesniewski, T.; Mahlik, S.; Grinberg, M.; Leniec, G.; Kaczmarek, S.M.; Lin, Y.-S.; Lu, K.-M.; et al. Super Broadband Near-Infrared Phosphors with High Radiant Flux as Future Light Sources for Spectroscopy Applications. ACS Energy Lett. 2018, 3, 2679-2684. [CrossRef]

9. Shao, Q.; Ding, H.; Yao, L.; Xu, J.; Liang, C.; Jiang, J. Photoluminescence properties of a ScBO3:Cr ${ }^{3+}$ phosphor and its applications for broadband near-infrared LEDs. RSC Adv. 2018, 8, 12035-12042. [CrossRef]

10. Shang, M.; Li, C.; Lin, J. How to produce white light in a single-phase host? Chem. Soc. Rev. 2014, 43, 1372-1386. [CrossRef]

11. Shao, Q.; Ding, H.; Yao, L.; Xu, J.; Liang, C.; Li, Z.; Dong, Y.; Jiang, J. Broadband near-infrared light source derived from $\mathrm{Cr}^{3+}$-doped phosphors and a blue LED chip. Opt. Lett. 2018, 43, 5251-5254. [CrossRef] [PubMed]

12. Pan, Z.; Lu, Y.-Y.; Liu, F. Sunlight-activated long-persistent luminescence in the near-infrared from Cr3+-doped zinc gallogermanates. Nat. Mater. 2011, 11, 58-63. [CrossRef]

13. Herbst, J.; Croat, J. Neodymium-iron-boron permanent magnets. J. Magn. Magn. Mater. 1991, 100, 57-78. [CrossRef]

14. Kränkel, C.; Marzahl, D.-T.; Moglia, F.; Huber, G.; Metz, P.W. Out of the blue: Semiconductor laser pumped visible rare-earth doped lasers. Laser Photon-Rev. 2016, 10, 548-568. [CrossRef]

15. Nakazawa, M. Evolution of EDFA from single-core to multi-core and related recent progress in optical communication. Opt. Rev. 2014, 21, 862-874. [CrossRef]

16. Xu, H.; Chen, R.; Sun, Q.; Lai, W.; Su, Q.; Huang, W.; Liu, X. Recent progress in metal-organic complexes for optoelectronic applications. Chem. Soc. Rev. 2014, 43, 3259-3302. [CrossRef] [PubMed]

17. Eliseeva, S.V.; Bünzli, J.-C.G. Lanthanide luminescence for functional materials and bio-sciences. Chem. Soc. Rev. 2010, 39, 189-227. [CrossRef]

18. Eliseeva, S.V.; Bünzli, J.-C.G. Rare earths: Jewels for functional materials of the future. New J. Chem. 2011, 35, 1165-1176. [CrossRef]

19. Zeng, H.; Zhou, T.; Wang, L.; Xie, R.-J. Two-Site Occupation for Exploring Ultra-Broadband Near-Infrared Phosphor-DoublePerovskite $\mathrm{La}_{2} \mathrm{MgZrO}_{6}: \mathrm{Cr}^{3+}$. Chem. Mater. 2019, 31, 5245-5253. [CrossRef]

20. Gao, T.; Zhuang, W.; Liu, R.; Liu, Y.; Yan, C.; Tian, J.; Chen, G.; Chen, X.; Zheng, Y.; Wang, L. Site occupancy and enhanced luminescence of broadband NIR gallogermanate phosphors by energy transfer. J. Am. Ceram. Soc. 2020, 103, 202-213. [CrossRef]

21. Zhong, Y.; Gai, S.; Xia, M.; Gu, S.; Zhang, Y.; Wu, X.; Wang, J.; Zhou, N.; Zhou, Z. Enhancing quantum efficiency and tuning photoluminescence properties in far-red-emitting phosphor Ca14Ga10Zn6O35:Mn4+ based on chemical unit engineering. Chem. Eng. J. 2019, 374, 381-391. [CrossRef]

22. Zhang, L.; Wang, D.; Hao, Z.; Zhang, X.; Pan, G.; Wu, H.; Zhang, J. Cr ${ }^{3+}$-Doped Broadband NIR Garnet Phosphor with Enhanced Luminescence and its Application in NIR Spectroscopy. Adv. Opt. Mater. 2019, 7, 1900185. [CrossRef]

23. Hemmer, E.; Benayas, A.; Légaré, F.; Vetrone, F. Exploiting the biological windows: Current perspectives on fluorescent bioprobes emitting above $1000 \mathrm{~nm}$. Nanoscale Horiz. 2016, 1, 168-184. [CrossRef] [PubMed]

24. Comby, S.; Bünzli, J.-C.G. Chapter 235 Lanthanide Near-Infrared Luminescence in Molecular Probes and Devices. Handbook on the Physics and Chemistry of Rare Earths; Elsevier: Amsterdam, The Netherlands, 2007.

25. Sabbatini, N.; Guardigli, M.; Lehn, J.-M. Luminescent lanthanide complexes as photochemical supramolecular devices. Co-Ord. Chem. Rev. 1993, 123, 201-228. [CrossRef]

26. Feng, J.; Zhang, H. Hybrid materials based on lanthanide organic complexes: A review. Chem. Soc. Rev. 2013, 42, 387-410. [CrossRef] [PubMed]

27. Li, J.; Li, H.; Yan, P.; Chen, P.; Hou, G.; Li, G. Synthesis, Crystal Structure, and Luminescent Properties of 2-(2,2,2-Trifluoroethyl)-1indone Lanthanide Complexes. Inorg. Chem. 2012, 51, 5050-5057. [CrossRef] [PubMed] 
28. Quirino, W.; Legnani, C.; dos Santos, R.; Teixeira, K.; Cremona, M.; Guedes, M.; Brito, H. Electroluminescent devices based on rare-earth tetrakis $\beta$-diketonate complexes. Thin Solid Films 2008, 517, 1096-1100. [CrossRef]

29. Divya, V.; Sankar, V.; Raghu, K.G.; Reddy, M.L.P. A mitochondria-specific visible-light sensitized europium $\beta$-diketonate complex with red emission. Dalton Trans. 2013, 42, 12317-12323. [CrossRef]

30. Biju, S.; Reddy, M.; Freire, R. 3-Phenyl-4-aroyl-5-isoxazolonate complexes of $\mathrm{Tb}^{3+}$ as promising light-conversion molecular devices. Inorg. Chem. Commun. 2007, 10, 393-396. [CrossRef]

31. Zhang, Z.; Yu, C.; Liu, L.; Li, H.; He, Y.; Lü, X.; Wong, W.-K.; Jones, R.A. Efficient near-infrared (NIR) luminescent PMMAsupported hybrid materials doped with tris- $\beta$-diketonate Ln3+ complex ( $\mathrm{Ln}=\mathrm{Nd}$ or $\mathrm{Yb}$ ). J. Photochem. Photobiol. A Chem. 2016, 314, 104-113. [CrossRef]

32. Werts, M.H. Making sense of Lanthanide Luminescence. Sci. Prog. 2005, 88, 101-131. [CrossRef]

33. Hasegawa, Y.; Wada, Y.; Yanagida, S. Strategies for the design of luminescent lanthanide(III) complexes and their photonic applications. J. Photochem. Photobiol. C Photochem. Rev. 2004, 5, 183-202. [CrossRef]

34. Bunzli, J.-C.; Comby, S.; Chauvin, A.-S.; Vandevyver, C.D. New Opportunities for Lanthanide Luminescence. J. Rare Earths 2007, 25, 257-274. [CrossRef]

35. Kuriki, K.; Koike, Y.; Okamoto, Y. Plastic Optical Fiber Lasers and Amplifiers Containing Lanthanide Complexes. Chem. Rev. 2002, 102, 2347-2356. [CrossRef] [PubMed]

36. Piszczek, G.; Gryczynski, I.; Maliwal, B.P.; Lakowicz, J.R. Multi-Photon Sensitized Excitation of Near Infrared Emitting Lanthanides. J. Fluoresc. 2002, 12, 15-17. [CrossRef]

37. Zhang, T.; Zhu, X.; Cheng, C.C.W.; Kwok, W.-M.; Tam, H.-L.; Hao, J.; Kwong, D.W.J.; Wong, W.-K. Water-Soluble MitochondriaSpecific Ytterbium Complex with Impressive NIR Emission. J. Am. Chem. Soc. 2011, 133, 20120-20122. [CrossRef] [PubMed]

38. D'Aléo, A.; Bourdolle, A.; Brustlein, S.; Fauquier, T.; Grichine, A.; Duperray, A.; Baldeck, P.L.; Andraud, C.; Brasselet, S.; Maury, O. Ytterbium-Based Bioprobes for Near-Infrared Two-Photon Scanning Laser Microscopy Imaging. Angew. Chem. Int. Ed. 2012, 51, 6622-6625. [CrossRef]

39. Bui, A.T.; Grichine, A.; Brasselet, S.; Duperray, A.; Andraud, C.; Maury, O. Unexpected Efficiency of a Luminescent Samarium(III) Complex for Combined Visible and Near-Infrared Biphotonic Microscopy. Chem.-A Eur. J. 2015, 21, 17757-17761. [CrossRef]

40. Vigato, P.A.; Peruzzo, V.; Tamburini, S. The evolution of $\beta$-diketone or $\beta$-diketophenol ligands and related complexes. Coord. Chem. Rev. 2009, 253, 1099-1201. [CrossRef]

41. Yu, C.; Zhang, Z.; Liu, L.; Feng, W.; Lü, X.; Wong, W.-K.; Jones, R.A. Near-infrared (NIR) luminescent PMMA-based hybrid materials doped with $\mathrm{Ln}-\beta$-diketonate $(\mathrm{Ln}=\mathrm{Nd}$ or $\mathrm{Yb})$ complexes. Inorg. Chem. Commun. 2014, 49, 30-33. [CrossRef]

42. Dang, S.; Yu, J.-B.; Wang, X.-F.; Guo, Z.-Y.; Sun, L.-N.; Deng, R.-P.; Feng, J.; Fan, W.-Q.; Zhang, H.-J. A study on the NIRluminescence emitted from ternary lanthanide [ $\mathrm{Er}(\mathrm{III}), \mathrm{Nd}(\mathrm{III})$ and $\mathrm{Yb}(\mathrm{III})]$ complexes containing fluorinated-ligand and 4,5diazafluoren-9-one. J. Photochem. Photobiol. A Chem. 2010, 214, 152-160. [CrossRef]

43. Ahmed, Z.; Iftikhar, K. Sensitization of Visible and NIR Emitting Lanthanide(III) Ions in Noncentrosymmetric Complexes of Hexafluoroacetylacetone and Unsubstituted Monodentate Pyrazole. J. Phys. Chem. A 2013, 117, 11183-11201. [CrossRef] [PubMed]

44. Martín-Ramos, P.; da Silva, P.S.P.; Lavín, V.; Martín, I.R.; Lahoz, F.; Chamorro-Posada, P.; Silva, M.R.; Martín-Gil, J. Structure and NIR-luminescence of ytterbium(III) beta-diketonate complexes with 5-nitro-1,10-phenanthroline ancillary ligand: Assessment of chain length and fluorination impact. Dalton Trans. 2013, 42, 13516-13526. [CrossRef]

45. Kang, T.-S.; Harrison, B.; Bouguettaya, M.; Foley, T.; Boncella, J.; Schanze, K.; Reynolds, J. Near-Infrared Light-Emitting Diodes (LEDs) Based on Poly(phenylene)/Yb-tris( $\beta$-Diketonate) Complexes. Adv. Funct. Mater. 2003, 13, 205-210. [CrossRef]

46. Knyazev, A.A.; Krupin, A.S.; Galyametdinov, Y.G. Luminescence behavior of PMMA films doped with Tb(III) and Eu(III) complexes. J. Lumin. 2021, 242, 118609. [CrossRef]

47. Knyazev, A.A.; Krupin, A.; Heinrich, B.; Donnio, B.; Galyametdinov, Y. Controlled polarized luminescence of smectic lanthanide complexes. Dye. Pigment. 2018, 148, 492-500. [CrossRef]

48. Baek, N.S.; Kim, Y.H.; Eom, Y.K.; Oh, J.H.; Kim, H.K.; Aebischer, A.; Gumy, F.; Chauvin, A.-S.; Bünzli, J.-C.G. Sensitized near-IR luminescence of lanthanide complexes based on push-pull diketone derivatives. Dalton Trans. 2010, 39, 1532-1538. [CrossRef]

49. Li, W.; Li, J.; Li, H.; Yan, P.; Hou, G.; Li, G. NIR luminescence of 2-(2,2,2-trifluoroethyl)-1-indone (TFI) neodymium and ytterbium complexes. J. Lumin. 2014, 146, 205-210. [CrossRef]

50. Baek, N.; Kwak, B.; Kim, Y.; Kim, H. Sensitized Near IR Luminescence of Er(III) Ion in Lanthanide Complexes Based on Diketone Derivatives: Synthesis and Photophysical Behaviors. Bull. Korean Chem. Soc. 2007, 28, 1256-1260. [CrossRef]

51. Knyazev, A.A.; Karyakin, M.E.; Romanova, K.A.; Heinrich, B.; Donnio, B.; Galyametdinov, Y.G. Influence of Lewis Bases on the Mesogenic and Luminescent Properties of Homogeneous Films of Europium(III) Tris( $\beta$-diketonate) Adducts. Eur. J. Inorg. Chem. 2017, 2017, 639-645. [CrossRef]

52. Knyazev, A.A.; Krupin, A.; Romanova, K.A.; Galyametdinov, Y. Luminescence and energy transfer in poly(N-vinylcarbazole) blends doped by a highly anisometric Eu(III) complex. J. Co-Ord. Chem. 2016, 69, 1473-1483. [CrossRef]

53. Knyazev, A.A.; Dzhabarov, V.I.; Lapaev, D.V.; Lobkov, V.S.; Haase, W.; Galyametdinov, Y.G. New nematogenic $\beta$-diketones for synthesis of lanthanidomesogens. Russ. J. Gen. Chem. 2010, 80, 756-760. [CrossRef]

54. Knyazev, A.A.; Galyametdinov, Y.G.; Goderis, B.; Driesen, K.; Goossens, K.; Görller-Walrand, C.; Binnemans, K.; Cardinaels, T. Liquid-Crystalline Ternary Rare-Earth Complexes. Eur. J. Inorg. Chem. 2008, 2008, 756-761. [CrossRef] 
55. Knyazev, A.; Karyakin, M.; Galyametdinov, Y. Photostable Anisometric Lanthanide Complexes as Promising Materials for Optical Applications. Photonics 2019, 6, 110. [CrossRef]

56. Knyazev, A.A.; Karyakin, M.E.; Heinrich, B.; Donnio, B.; Galyametdinov, Y.G. A facile approach for the creation of heteroionic lanthanidomesogens-containing uniform films with enhanced luminescence efficiency. Dye. Pigment. 2020, 187, 109050. [CrossRef]

57. Lapaev, D.V.; Nikiforov, V.G.; Lobkov, V.S.; Knyazev, A.A.; Krupin, A.S.; Galyametdinov, Y.G. New insights into UV laser irradiation effect on luminescent behavior of vitrified films based on mesogenic lanthanide(III) $\beta$-diketonate complexes. $J$. Photochem. Photobiol. A Chem. 2019, 382, 111962. [CrossRef]

58. Caspers, H.H.; Miller, S.A.; Rast, H.E.; Fry, J.L. Electronic Spectrum and Energy Levels of Gd ${ }^{3+}$ in LaF 3 . Phys. Rev. 1969, 180, 329-333. [CrossRef]

59. Moore, E.G.; Samuel, A.P.S.; Raymond, K.N. From Antenna to Assay: Lessons Learned in Lanthanide Luminescence. Acc. Chem. Res. 2009, 42, 542-552. [CrossRef]

60. Li, S.; Zhu, W.; Xu, Z.; Pan, J.; Tian, H. Antenna-functionalized dendritic $\beta$-diketonates and europium complexes: Synthetic approaches to generation growth. Tetrahedron 2006, 62, 5035-5048. [CrossRef]

61. Bünzli, J.-C.G. Lanthanide Luminescence for Biomedical Analyses and Imaging. Chem. Rev. 2010, 110, 2729-2755. [CrossRef]

62. Knyazev, A.A.; Karyakin, M.; Krupin, A.; Galyametdinov, Y. Synthesis and luminescence properties of hybrid systems based on liquid crystal terbium(III) and europium(III) complexes. Russ. J. Gen. Chem. 2015, 85, 2806-2812. [CrossRef]

63. Knyazev, A.; Krupin, A.; Gubaidullin, A.; Galyametdinov, Y. Optical and structural characteristics of PMMA films doped with a new anisometric EuIII complex. Acta Crystallogr. Sect. B Struct. Sci. Cryst. Eng. Mater. 2019, 75, 570-577. [CrossRef] 